Michał BRZOZOWSKI ${ }^{1}$, Krzysztof PARCZEWSKI ${ }^{2}$

DOI: https://doi.org/10.53052/9788366249837.02

\title{
WPLYW NIEKORZYSTNYCH WARUNKÓW ATMOSFERYCZNYCH NA DZIAŁANIE SENSORÓW WYKORZYSTYWANYCH W SAMOCHODACH AUTONOMICZNYCH
}

\begin{abstract}
Streszczenie: Celem artykułu jest objaśnienie wpływu niekorzystnych warunków pogodowych na najbardziej popularne sensory wykorzystywane w samochodach autonomicznych. W pracy przedstawiono typowe sensory takie jak: kamera, LiDAR oraz RADAR, a następnie wskazano zakłócenia jakie w ich pracy wywołują niekorzystne warunki pogodowe. Przedstawiono wpływ: deszczu, śniegu oraz mgły. Ponadto omówiono próby zmierzające do ograniczenia tego wpływu. Proponowane działania dotyczą zarówno usprawnień samego sprzętu jak i rozwijania metod analizy obrazu. Podsumowaniem opracowania jest konkluzja, że najlepsze efekty otrzymuje się podczas wykorzystywania różnych sensorów, które mogą się wzajemnie uzupełniać.
\end{abstract}

Słowa kluczowe: samochód autonomiczny, jazda autonomiczna, pogoda, niesprzyjające warunki atmosferyczne, kamera, LiDAR, radar

\section{THE INFLUENCE OF ADVERSE WEATHER CONDITIONS ON THE OPERATION OF SENSORS USED IN AUTONOMOUS CARS}

Summary: The aim of the article is to explain the influence of unfavorable (adverse) weather conditions on the most popular sensors used in autonomous cars. The paper presents typical sensors such as: camera, LiDAR and radar, and then indicates the disruptions caused by unfavorable weather conditions in their work. Influence of: rain, snow and fog is presented. In addition, attempts to reduce this impact were discussed. The proposed actions concern both the improvement of the equipment itself and the development of image analysis methods. The summary of the study is the conclusion that the best results are obtained when using various sensors that can complement each other

Keywords: autonomous car, autonomous driving, weather, adverse weather conditions, camera, LiDAR, radar.

mgr inż., Akademia Techniczno - Humanistyczna w Bielsku-Białej, michalbrzozowski1995@gmail.com

${ }^{2}$ dr hab. inż., prof. ATH, Akademia Techniczno-Humanistyczna w Bielsku-Białej Wydział Budowy Maszyn i Informatyki, Katedra Silników Spalinowych i Pojazdów, kparczewski@ath.bielsko.pl 


\section{Wstęp}

Samochody autonomiczne znajdują się w awangardzie rozwijanych technologii motoryzacyjnych. Systemy jazdy autonomicznej, takie jak na przykład aktywny tempomat, już teraz pojawiają się powszechnie w samochodach komercyjnych. Celem wprowadzania tych technologii, jest przede wszystkim podniesienie poziomu bezpieczeństwa oraz wspomożenie kierowcy [5]. Dlatego rozwijanie tych systemów stało się priorytetem zarówno dla producentów jak i dla badaczy.

Zgodnie z powszechnie przyjętą klasyfikacją SAE (Society of Automotive Engineers) wyróżnia się pięć poziomów autonomiczności. Najwyższy, piąty poziom zakłada, że jazda autonomiczna odbywa się bez udziału kierowcy, niezależnie od warunków pogodowych [44]. Aby móc samodzielnie nawigować, samochód autonomiczny wykorzystuje dane otrzymywane $\mathrm{z}$ sensorów analizujących otoczenie. Bazując na tych danych, działają algorytmy i systemy odpowiedzialne za jazdę i bezpieczeństwo. Obecnie, stworzenie pojazdu autonomicznego, który mógłby poruszać się w nieznanym terenie przy niesprzyjających warunkach pogodowych (deszcz, śnieg, mgła) wciąż stanowi duże wyzwanie [55, 2, 36, 37, 47]. Woda jest w stanie zalegać na obiektywie i zamazywać obraz, a strugi deszczu rozpraszają i wchłaniają światło wiązki lasera [22]. Śnieg zalegający na jezdni przykrywa znaki drogowe (pionowe i poziome) i zniekształca obraz [5]. Mgła drastycznie ogranicza widoczność i zasłania pole widzenia kamery. Dlatego właśnie, zła pogoda już teraz stanowi problem dla wykorzystywanych systemów jazdy autonomicznej takich jak na przykład systemy detekcji znaków drogowych $[53,28]$. Ponadto, pogoda może wpływać na prawidłowe funkcjonowanie pojazdu autonomicznego nie tylko poprzez zakłócanie pracy sensorów ale także poprzez zmieniające się warunki przyczepności opon do jezdni, a tym samym możliwości przenoszenia sil trakcyjnych. Kiedy jezdnia staje się śliska, pojazd autonomiczny musi na nowo obliczyć swoją trajektorię ruchu. Wielu autorów twierdzi, że zmiana pogody wymaga natychmiastowego uwzględnienia w systemach planowania i sterowania ruchem pojazdu autonomicznego [53, 33, 25]. Jest to związane z tym, że zakłócenie pracy czujników prowadzi do powstania białych plam informacyjnych - sytuacji, w których nie ma wystarczającej ilości danych potrzebnych do prawidłowej estymacji, lokalizacji, detekcji, a to utrudnia podejmowanie decyzji przez układ sterowania samochodem [26]. Dlatego właśnie przyjmuje się, że pojazd autonomiczny musi uzyskać minimum informacji wymaganych do prawidłowego funkcjonowania nawet podczas jazdy w niesprzyjającej pogodzie [10]. Taka pogoda stanowi wyzwanie dla ludzi kierowców i tym bardziej jest ona przeszkodą dla samochodów autonomicznych.

\section{Przedstawienie sensorów wykorzystywanych w samochodzie autonomicznym}

Za analizę otoczenia odpowiedzialne są czujniki zabudowane w samochodzie autonomicznym. W pojazdach autonomicznych najczęściej wykorzystuje się sensory takie jak: kamery, LiDAR (Light Detection and Ranging) i Radar (Radio Detection and Ranging) [8, 19]. W dalszej części przedstawiony zostanie wpływ niesprzyjających warunków atmosferycznych na każdy z tych czujników, oraz 
omówienie zakłóceń jakie wówczas powstają. Zostaną także zaprezentowane metody nacelowane na przeciwdziałanie tym zakłóceniom.

W tabeli 1 przedstawiono zestawienie trzech najpopularniejszych sensorów wykorzystywanych w samochodzie autonomicznym, a także możliwości ich zastsowania. Ponadto, wyszczególnione są potencjalne trudności wynikające z trzech najpopularniejszych niekorzystnych zjawisk atmosferycznych.

Tabela 1. Zestawienie sensorów, możliwości ich wykorzystania oraz możliwych efektów wywołanych przez niesprzyjajace warunki atmosferyczne. Źródto: opracowanie wtasne.

\begin{tabular}{|c|c|c|c|c|}
\hline Sensor & Zastosowanie & Deszcz & Mgła & Śnieg \\
\hline Kamera & 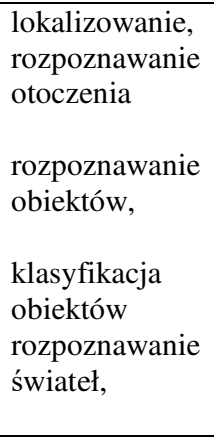 & $\begin{array}{l}\text { Pogorszenie } \\
\text { jakości obrazu, } \\
\text { Możliwy } \\
\text { całkowity } \\
\text { paraliż pracy } \\
\text { urządzenia, } \\
\text { Zniekształcenie } \\
\text { kształtu } \\
\text { obiektów, }\end{array}$ & $\begin{array}{l}\text { Znaczne } \\
\text { pogorszenie } \\
\text { jakości obrazu, } \\
\text { Możliwy } \\
\text { całkowity } \\
\text { paraliż pracy } \\
\text { urządzenia, } \\
\text { Zniekształcenie } \\
\text { kształtu } \\
\text { obiektów, }\end{array}$ & $\begin{array}{l}\text { Znaczne } \\
\text { pogorszenie } \\
\text { jakości obrazu, } \\
\text { Możliwy } \\
\text { całkowity paraliż } \\
\text { pracy urządzenia, } \\
\text { Zniekształcenie } \\
\text { kształtu obiektów, }\end{array}$ \\
\hline LiDAR & $\begin{array}{l}\text { lokalizowanie, } \\
\text { rozpoznawanie } \\
\text { otoczenia, } \\
\text { rozpoznawanie } \\
\text { obiektów, } \\
\text { klasyfikacja } \\
\text { obiektów, } \\
\text { śledzenie } \\
\text { obiektów, }\end{array}$ & $\begin{array}{l}\text { Spadek } \\
\text { współczynnika } \\
\text { odblaskowości, } \\
\text { Spadek zasięgu } \\
\text { wykrywania, } \\
\text { Spadek liczby } \\
\text { wykrywanych } \\
\text { punktów, } \\
\text { Zniekształcenie } \\
\text { kształtu i } \\
\text { wykrywanie } \\
\text { fantomowych } \\
\text { obiektów }\end{array}$ & $\begin{array}{l}\text { Spadek } \\
\text { współczynnika } \\
\text { odblaskowości, } \\
\text { Znaczny spadek } \\
\text { zasięgu } \\
\text { wykrywania, } \\
\text { Spadek liczby } \\
\text { wykrywanych } \\
\text { punktów, } \\
\text { Zniekształcenie } \\
\text { kształtu } \\
\text { obiektów }\end{array}$ & $\begin{array}{l}\text { Spadek } \\
\text { współczynnika } \\
\text { odblaskowości, } \\
\text { Spadek zasięgu } \\
\text { wykrywania } \\
\text { Spadek liczby } \\
\text { wykrywanych } \\
\text { punktów, } \\
\text { Zniekształcenie } \\
\text { kształtu i } \\
\text { wykrywanie } \\
\text { fantomowych } \\
\text { obiektów, } \\
\text { Powstawanie } \\
\text { szumu }\end{array}$ \\
\hline $\begin{array}{l}\text { Radar } \\
\text { (77GHz) }\end{array}$ & $\begin{array}{l}\text { lokalizowanie, } \\
\text { rozpoznawanie } \\
\text { obiektów, } \\
\text { śledzenie } \\
\text { obiektów. }\end{array}$ & $\begin{array}{l}\text { Spadek zasięgu } \\
\text { wykrywania, } \\
\text { Spadek } \\
\text { wiarygodności } \\
\text { otrzymanych } \\
\text { danych. }\end{array}$ & $\begin{array}{l}\text { Spadek zasięgu } \\
\text { wykrywania, } \\
\text { Spadek } \\
\text { wiarygodności } \\
\text { otrzymanych } \\
\text { danych. }\end{array}$ & $\begin{array}{l}\text { Spadek zasięgu } \\
\text { wykrywania, } \\
\text { Spadek } \\
\text { wiarygodności } \\
\text { otrzymanych } \\
\text { danych. }\end{array}$ \\
\hline
\end{tabular}


Jak zostało to przedstawione $\mathrm{w}$ tabeli 1, niesprzyjające warunki atmosferyczne wywołują wiele negatywnych efektów o różnej istotności. Każdy z nich jest potencjalnie niebezpieczny, ponieważ może negatywnie wpływać na funkcjonowanie i bezpieczeństwo ruchu samochodu autonomicznego. Dlatego, dąży się do zniwelowania wpływu tych efektów lub jeśli to niemożliwe to przynajmniej do zminimalizowania ich wpływu. Poniżej przedstawiono krótką charakterystykę wpływu warunków atmosferycznych na działanie przedstawionych powyżej czujników.

\subsection{Kamera}

Kamera to obecnie najpopularniejszy sensor wykorzystywany w pojazdach autonomicznych. Kamery są tanie, łatwe do implementacji i dostarczają informacji bogatych semantyczne, dzięki czemu dobrze sprawdzają się jako narzędzie do klasyfikacji obiektów [8, 28]. Jednakże, są one bardzo wrażliwe na niesprzyjające warunki pogodowe [10]. Dowiedziono, że już nawet pojedyncza kropla wody na obiektywie może rozproszyć światło zamazując pole widzenia nawet do 165 stopni [15].

Większość algorytmów stosowanych w systemach wizyjnych zakłada, że natężenie światła jest proporcjonalne do jasności sceny. Jednakże, dynamicznie zmieniające się warunki pogodowe (deszcz i śnieg) wprowadzają ostre fluktuacje intensywności w obrazach i filmach, które degradują jakość obrazu, a tym samym naruszają to podstawowe założenie. Na przykład krople deszczu znajdujące się w powietrzu (strugi) mogą tworzyć wzór na obrazie, co zmniejsza intensywność obrazu i rozmywa krawędzie innych wzorów za nim [56]. Eksperyment przeprowadzony przez Ferreira i Martins wykazał, że realizując zadanie detekcji pojazdu w deszczu, jakość pracy kamery obniżona jest głównie $\mathrm{z}$ powodu słabego nasycenia gradientu co na późniejszym etapie przetwarzania obrazu skutkuje problemami w stworzeniu obwiedni wykrywanego pojazdu - algorytm ma problem przy ograniczeniu pola obrazu, na którym widoczny jest pojazd [12]. Jest to istotny problem, ponieważ wiele algorytmów detekcyjnych działa w oparciu o tę metodę. Na podstawie badań eksperymentalnych odnotowano spadek jakości wykrywania o 21\%. Inny eksperyment wykazał spadek skuteczności wykrywania do 65\% w trakcie opadów deszczu oraz do $45 \%$ w trakcie burzy (za 100\% przyjęto wyniki otrzymywane przy czystym niebie) [58].

Mgła, chociaż jest rzadkim zjawiskiem atmosferycznym, ma duży wpływ na pracę kamery. Przede wszystkim, sprawia ona, że efektywny zakres widzenia kamery znacząco się kurczy, tym samym wykrywanie tylnych świateł pojazdu poprzedzającego czy krawędzi drogi staje się bardzo trudne. Te same problemy można odnieść do znacznie częściej występujących opadów śniegu. Jest to poważny problem, ponieważ nawet jeśli samochód autonomiczny korzysta z metod lokalizacji takich jak wcześniej przygotowane mapy otoczenia to zalegający śnieg może prowadzić do poważnych błędów w lokalizacji [55].

Podstawową metodą służącą do niwelowania wpływu strug deszczu na pracę kamery jest ustawianie odpowiednich parametrów. Badania dowodzą, że przynosi to rezultat w przypadku deszczu padającego z małą prędkością i intensywnością. Silny deszcz, pomimo zmian parametrów wciąż zakłóca pracę kamery, obniżając kontrast i zmniejszając intensywność nasycenia pikseli [12]. Inną metodą jest wykorzystanie 
filtrów polaryzacyjnych i technik opartych o polarymetrię [46, 11]. Działanie to polega na dokładniejszej charakteryzacji światła odbitego od danego obiektu. Techniki te pozwalają opisać ważne fizyczne właściwości takie jak strukturę powierzchni, rodzaj materiału czy jego szorstkość. Dzieje się tak, ponieważ stan polaryzacji odbitego światła jest ściśle związany z fizycznymi cechami widzianego obiektu. Według Blin i Ainouz wykorzystanie polarymetrii zwiększa jakość detekcji w trudnych warunkach nawet do $20 \%$ [4].

Następną próbą zwiększenia jakości wykrywania podczas niekorzystnych warunków pogodowych jest stosowanie wyznaczników (ang. prior). Metodę tę stosuje się w przypadku analizowania obrazu pochodzącego z dwóch kamer (stereowizji). Metoda ta polega na wcześniejszym ustaleniu informacji niezależnych od obecnie analizowanego obrazu. Ostatecznie, ma to na celu zmniejszenie liczby fałszywych interpretacji obiektów. Przeprowadzony eksperyment [16] dowodzi, że metoda ta faktycznie działa i zwiększa dokładność wykrywania o ponad $2 \%$.

Kolejne próby mające na celu zniwelowanie wpływu deszczu na pracę kamery polegają na zastosowaniu algorytmów służących do usuwania deszczu z obrazu. Przykłady takich algorytmów to: DDN [14], DeRaindropm [40], PreNet [43], UNIT [34]. Algorytmy tego typu mają za zadanie usunąć efekty deszczu i przywrócić obraz do wersji nie zakłóconej przez krople i strugi, tym samym zwiększając jakość obrazu i ilość widocznych detali. W ramach eksperymentu, badacze przetestowali wymienione algorytmy. Najpierw ustalono, że deszcz powoduje spadek wykrywalności obiektów (samochodów i pieszych) rzędu kilku do kilkunastu procent - co zgadza się z wynikami wcześniej przytaczanych badań. Aby to stwierdzić, przeprowadzili próby przy czystym niebie oraz w czasie deszczu, a do identyfikacji wykorzystali algorytmy Faster R-CNN [17] oraz YOLO [42]. Następnie, na materiale pozyskanym podczas badań w deszczu, wykonali oni operację usuwania wpływu deszczu za pomocą DDN, DeRaindrop, PreNet oraz UNIT i raz jeszcze wykorzystali algorytmy służące do identyfikacji. Przeprowadzony eksperyment wykazał, że wygładzanie obrazu (działanie algorytmu usuwającego deszcz) nie zapewniało lepszej widoczności obiektów i tym samym wyniki detekcji były gorsze niż w przypadku analizy surowego obrazu z deszczem (za wyjątkiem algorytmu UNIT, w kilku przypadkach). Nieco inne wyniki otrzymali badacze [52], którzy testowali algorytm usuwający deszcz z obrazu pod kątem lokalizacji pojazdu autonomicznego. W ramach eksperymentu wykazali znaczną poprawę. Odmienny wynik może być związany $\mathrm{z}$ faktem, że lokalizacja $\mathrm{w}$ otoczeniu nie wymaga tak precyzyjnego określania kształtu jak detekcja obiektów i dodatkowo pozwala wykorzystać wcześniej przygotowane mapy. Tak czy inaczej, wszyscy badacze konkludują, że problem prawidłowego rozpoznawania obiektów w deszczu jest daleki od rozwiązania [24].

Obecne technologie usuwania efektów mgły z obrazu na już uchwyconym obrazie, można podzielić na dwa rodzaje: korekcja mgły i usuwanie mgły z obrazu. Korekcja mgły polega na zmianie poziomu kontrastu, na przykład poprzez korekcję kolorów. W procesie usuwania mgły, poziom mgły nad obrazem jest szacowany i usuwany [51]. Inną metodą służącą do rozwiązania problemu pracy kamery we mgle jest stosowanie specjalnych kamer wykorzystujących podczerwień lub kamer, których praca połączona jest $\mathrm{z}$ działaniem lasera (ang. gated camera) [55]. Obiektyw jest sprzężony z laserem i w pewnym momencie laser na bardzo krótki czas oświetla cele na danym dystansie tak aby mogły być zauważone przez obiektyw kamery. 
Przeprowadzone badania wykazują, że w tym przypadku kamera działa znacznie skuteczniej od standardowej [3]. Dodatkowo, prowadzone są badania nad wykorzystaniem sztucznych sieci neuronowych do analizy obrazów RGB w celu rozpoznawania otoczenia drogi nawet we mgle [45].

Zwiększenie jakości pracy kamery w trakcie opadów śniegu polega przede wszystkim na zastosowaniu precyzyjnych systemów lokalizacji RTK-GNSS oraz wykorzystaniu innych sensorów, takich jak radar. To jednak nie rozwiązuje problemu w całości, gdyż dane dostarczane przez radar (np. dotyczące kształtu) są znacznie mniej precyzyjne [55].

Podsumowując, metody mające na celu usprawnienie jakości działania kamery w trudnych warunkach atmosferycznych, można podzielić na: próby skonstruowania specjalnego, dedykowanego tym zadaniom sprzętu i metody oparte o poprawę jakości analizy obrazu. W przy przypadku tych drugich metod, najlepiej rokujące są sztuczne sieci neuronowe [20,32]. Sieci te wykorzystuje się także do łączenia informacji płynących z różnych sensorów aby w ten sposób zwiększyć jakość detekcji i jej dokładność [7].Warto zauważyć, że wpływ warunków atmosferycznych na pracę kamery jest na tyle istotny, że podejmuje się wiele prób tworzenia baz danych i wyszukanych metod ewaluacji, tak aby zapewnić możliwie rzeczywiste warunki do testowania nowych rozwiązań nie wymagających każdorazowego budowania od podstaw skomplikowanych stanowisk badawczych $[9,22]$.

\subsection{LiDAR}

Wykorzystywanie skanerów laserowych w samochodach autonomicznych spopularyzowało się w wyniku obniżenia ich kosztów, wielkości i skomplikowania [58]. Cieszą się one popularnością bo zapewniają wiarygodne dane, mają daleki zasięg działania i mogą służyć zarówno do identyfikacji jak i do śledzenia obiektów. Najczęściej wykorzystywanymi LiDARami są LiDARy pulsacyjne. Ogólna zasada ich działania polega na mierzeniu czasu w jakim wyemitowana wiązka promieni lasera odbija się od obiektu i powraca do czujnika. Następnie generowana są dane w postaci chmury punktów, która zawiera informacje o ich położeniu oraz intensywności danych punktów. $\mathrm{Na}$ podstawie tych informacji, algorytmy przetwarzania obrazu dokonują identyfikacji i klasyfikacji otoczenia i obiektów. Chociaż LiDARy są uznawane za niezawodne i precyzyjne, a także bardziej odporne na warunki atmosferyczne niż kamery to one także są wrażliwe na warunki pogodowe $[10,18,13]$.

W przypadku kamer, już nawet sama obecność kropli wody na powierzchni czujnika może prowadzić do znacznego pogorszenia jakości otrzymywanego obrazu, natomiast $\mathrm{w}$ przypadku LiDARu, Wojtanowski, Zygmunt i inni [50] dowodzą, że bardziej niebezpieczna jest woda na powierzchni namierzanych obiektów lub obecna w powietrzu w postaci kropel deszczu. Może to bowiem prowadzić do szeregu niekorzystnych efektów takich jak: pogorszenie współczynnika odbicia, spadku efektywnego zasięgu i przekłamania kształtu identyfikowanego obiektu [58]. Im bardziej intensywny deszcz tym bardziej efekty te się nasilają - deszcz o intensywności $15 \mathrm{~mm} / \mathrm{h}$ nie jest jeszcze groźny ale już przy intensywności na poziomie 30mm/h obniża się skuteczny zasięg pracy LiDARu o 50\% [21]. Ważny jest także kształt i wielkość kropel gdyż większe krople bardziej zniekształcają wiązkę [56]. Natomiast malejąca liczba wygenerowanych punktów, nie tylko skutkuje 
zmniejszaniem zasięgu ale także ogranicza liczbę danych dostępnych do analizy [3]. Ponadto, w wyniku rozbryzgiwania wody przez inne pojazdy, może dochodzić do wykrywania fałszywie istniejących punktów i w konsekwencji do generowania fantomowych (nierzeczywistych) obiektów [41]. Efekt ten prowadzi do powiększenia rzeczywistego obiektu o nieistniejące punkty co stanowi poważne utrudnienie dla algorytmów, które (w następnym kroku) dokonują klasyfikacji obiektów. Zakrzywienie kształtu może bowiem spowodować złe dopasowanie klasy obiektu. Wynika to $\mathrm{z}$ faktu, że chociaż fantomowe punkty mają z zasady niską intensywność to w wyniku deszczu intensywność istniejących punktów także spada. Dlatego, wykorzystanie zwyczajnego algorytmu filtrującego opartego o intensywność mogłoby doprowadzić do utraty wielu istniejących punktów [12]. Tym samym, deszcz powoduje znaczne utrudnienie w stosowaniu algorytmów analizy obrazu (chmury punktów). Eksperymenty wykazują, że ogólna skuteczność detekcji w warunkach deszczu spada od kilku do kilkunastu procent [58].

Wedle badań Hesper Riviere i innych [23], dla LiDARu emitującego fale o długości 905 nanometrów (95\% obecnie wykorzystywanych urządzeń), mgła stanowi większe wyzwanie niż deszcz. Wynika to z rozpraszania światła przez cząsteczki mgły. Przy czym im mgła jest gęstsza tym większe problemy ma czujnik z dostarczaniem rzetelnych informacji. Testy w komorze wykazują, że detekcja celu w odległości $10.5 \mathrm{~m}$ przy widoczności $10 \mathrm{~m}$ jest niemożliwa, dla większości LiDARów. Dopiero podniesienie poziomu widoczności do $15 \mathrm{~m}$ spowodowało, że cel stał się dobrze widoczny [27]. Podobnie efekty co mgła wywołuje także zapylenie (zwłaszcza cząstkami PM10)[3].

Śnieg, oprócz negatywnych efektów wymienionych już dla deszczu i mgły, wprowadza dodatkowo efekt szumu. Płatki śniegu są większe niż krople wody i spadają wolniej, dlatego mogą być wykrywane przez LiDAR. Jeżeli pojazd porusza się za innym pojazdem powstaje dodatkowo zjawisko wiru, który powoduje kolejne utrudnienia zwłaszcza w kontekście śledzenia pojazdu poprzedzającego. Niemniej, ze względu na swą charakterystykę to mgła powoduje największe utrudnienie pracy LiDARu.

Podejmowane są różne próby usprawnienia pracy LiDARu podczas deszczu. Pierwsze $\mathrm{z}$ nich, podobnie jak w przypadku kamer, dotyczą samego sprzętu i sprowadzają się do: dobierania optymalnej długości fal, dopasowywania możliwych zakresów mocy i optymalizacji elementów optycznych i elektronicznych [30]. Druga grupa prób dotyczy oprogramowania wykorzystywanego do przetwarzania pozyskanych danych. Jeżeli LiDAR jest wykorzystywany do lokalizacji samochodu autonomicznego, zadanie to jest prostsze ponieważ pozwala wykorzystać wcześniej przygotowane mapy otoczenia. Wówczas, stosuje się algorytmy nacelowane na zwiększenie intensywności, która została obniżona w wyniku padającego deszczu, tak aby można było określić szukane cechy otoczenia [1]. Wykorzystuje się do tego różnego rodzaju filtry (np. cząsteczkowy) optymalizując ich działanie pod kątem mokrych powierzchni [57].

Zadanie usprawnienia pracy LiDARu bez możliwości wsparcia się na mapach jest trudniejsze. Większość metod rozwiązania tego problemu to różne wariacje: algorytmów filtrujących lub optymalizacyjnych, a także sztucznych sieci neuronowych [38]. Za przykład innych metod może posłużyć system porównujący pozycję danego punktu na kolejnych skanach. Do zastosowania dodatkowego 
algorytmu ułatwiającego analizę obrazu konieczne jest prawidłowe rozpoznanie danego zjawiska atmosferycznego, co samo w sobie stanowi trudność [3].

Sposobem rozwiązania problemu działania LiDARu we mgle, może być wykorzystanie LiDARów o fali długości $1550 \mathrm{~nm}$. Wedle zwolenników tego rozwiązania [35]., dłuższa fala mniej rozprasza się we mgle. Natomiast sposobem na usprawnienie pracy LiDARu podczas opadów śniegu jest stosowanie algorytmów przywracających utracone informacje [6].

\subsection{Radar}

Radar to sensor, który już teraz jest na szeroką skalę wykorzystywany w samochodach komercyjnych. Służy do dostarczania wiarygodnych informacji o odległości i prędkości analizowanego obiektu dzięki efektowi Dopplera. Większość radarów działa w oparciu o fale o długości 77GHz [8].

Chociaż uznaje się, że radar jest najbardziej odporny na warunki atmosferyczne spośród wszystkich popularnych sensorów wykorzystywanych w samochodach autonomicznych, to jednak wpływ niekorzystnych warunków pogodowych również jest obserwowalny. Część fali radiowej może być pochłaniana przez kropelki wody w powietrzu (efekt tłumienia), fala może być także depolaryzowana lub rozproszona przez deszcz [12]. Najbardziej zaburza pracę radaru występowanie rozpraszania wstecznego. Efekt ten ma miejsce ponieważ rozmiar kropli wody jest porównywalny $\mathrm{z}$ długością fali radiowej (milimetrowej). Efekt tłumienia zmniejsza odbieraną moc sygnałów, a efekt rozproszenia wstecznego zwiększa zakłócenia w odbiorniku [55]. Większość badań dowodzi, że deszcz nie ma dużego wpływu na zasadniczą pracę radaru jaką jest wykrywanie obiektów [58, 55]. Jednakże w przypadku bardziej skomplikowanych zadań jak chociażby określanie kształtu obiektów deszcz negatywnie wpływa na możliwości działania sensora [22]. Kolejnym zauważalnym efektem jest spadek efektywnego zasięgu wynikający z opadów deszczu. Jest on jednak znacznie słabszy niż w przypadku LiDARu, dla deszczu o intensywności $50 \mathrm{~mm} / \mathrm{h}$ zasięg spada o $11 \%$, a znaczne obniżenie zasięgu działania radaru powoduje deszcz o intensywności $150 \mathrm{~mm} / \mathrm{h}$ (dla LiDARa jest to $30 \mathrm{~mm} / \mathrm{h}$ ) [56]. Przy czym, im mniejszy jest wykrywany obiekt, tym szybciej zasięg będzie spadał. Jest to szczególnie istotne np. w przypadku wykrywania pieszych [48]. Badania dowodzą, że dla operacji na zasięgu do $25 \mathrm{~m}$, mgła ma pomijalny wpływ na działanie radaru. Jednakże w przypadku śniegu, dystans wykrywania spada o 25\% [35].

Największą przeszkodą wpływającą na wykorzystanie radaru w niesprzyjających warunkach pogodowych jest fakt, że sensor ten dostarcza informacje o małej ilości szczegółów. W przypadku samochodu autonomicznego, sama możliwość dostrzeżenia przeszkody lub śledzenia jej nie wystarcza. Dlatego jednym z rozwiązań możliwych do zastosowania w przypadku radaru jest zwiększenie rozdzielczości (dokładności) jego wskazań np. poprzez budowę urządzeń działających na falach 79GHz. Ponadto trwają prace nad stworzeniem systemu składającego się z kilku radarów, generujących mapę niemalże w technologii 3D [48]. 


\section{Podsumowanie}

Warunki atmosferyczne mają zasadniczy wpływ na pracę sensorów wykorzystywanych w samochodach autonomicznych. Deszcz czy mgła powodują zmniejszenie zasięgu i pola widzenia czujników, utrudniają lokalizację i identyfikację obiektów, a nawet mogą prowadzić do detekcji nieistniejących przeszkód. W tabeli 1 przedstawiono problemy wywołane przez niekorzystne zjawiska atmosferyczne z jakimi należy się zmierzyć podczas analizy obrazu w odniesieniu do stosowanych czujników w samochodach autonomicznych. Z zestawienia wynika, że sensorem najbardziej odpornym na złe warunki atmosferyczne jest radar, jednakże nawet jego możliwości są ograniczane przez złe warunki pogodowe. Analiza danych zawartych w tabeli pozwala stwierdzić, że to śnieg jest zjawiskiem atmosferycznym stwarzającym największe niebezpieczeństwo. Oprócz paraliżu działania samych urządzeń, może on także zalegać na jezdni i na obiektach (samochodach, znakach) co może prowadzić do poważnych błędów w rozpoznawaniu otoczenia.

Największa strata jakości uzyskiwanych danych ma miejsce w przypadku czujników typu kamera. Deszcz o średniej intensywności jest w stanie mocno obniżyć jakość wychwytywanego obrazu, a śnieg czy mgła tylko wzmagają ten problem. Zwłaszcza mgła powoduje, że sensor ten traci możliwość wypełnienia swojego podstawowego zadania i tym samym, staje się mało użyteczny. Na podstawie badań określono spadek wykrywania obiektów w zależności od intensywności deszczu o 21 do 65\%, a w przypadku mgły nawet do $100 \%$.

Dla czujników typu LiDAR, mgła stanowi największe wyzwanie, ponieważ rozprasza ona światło. Opady deszczu, znacznie częściej występujące, także stanowią istotne utrudnienie dla pracy tego sensora. Duże krople deszczu rozpraszają światło, a mokra powierzchnia identyfikowanych obiektów obniża współczynnik odbicia światła. Ponadto pojawia się problem z fantomowymi obiektami. W przypadku LiDARu zasięg wykrywanych obiektów, w zależności od intensywności deszczu, zmniejsza się o 20 nawet do $65 \%$.

Radar, chociaż spośród zestawionych sensorów jest najbardziej odporny na zakłócenia wynikające ze złej pogody, także w jej wyniku traci część swoich możliwości. Dzieje się tak zwłaszcza podczas intensywnych opadów deszczu, kiedy fala radiowa jest tłumiona i pochłaniana przez krople wody znajdujące się w powietrzu. W przypadku radaru zasięg wykrywanych obiektów w zależności od intensywności deszczu zmniejsza się o $11 \%$ a w przypadku opadów śniegu nawet do $25 \%$.

Jak przedstawiono powyżej, każdy $\mathrm{z}$ opisanych sensorów jest w innym stopniu podatny na dany rodzaj zakłócenia. Dlatego, systemy wykorzystujące jednocześnie różnego typu sensory, które mogą się wzajemnie uzupełniać, zdają się być najlepszą metodą rozwiązania tych problemów. W takim przypadku kamera może dostarczać informacji bogatych semantycznie, a radar i LiDAR odpowiadać za namierzanie i śledzenie obiektu.

Innym sposobem jest wykorzystanie algorytmów pozwalających na lepszą interpretację uzyskanych danych. Rozwój sieci neuronowych sprzyja tworzeniu systemów wykorzystujących łączenie różnego rodzaju czujników, ponieważ to właśnie na nich najczęściej opiera się ich architektura [20,39]. Potwierdzają to wyniki badań eksperymentalnych przeprowadzonych w Seulu, polegających na wykorzystaniu kamery i LiDARu jako rozwiązania problemu poruszania się 
samochodu autonomicznego w deszczu. Badanie przeprowadzono podczas słonecznej pogody oraz w trakcie lekkiego deszczu. Chociaż deszcz obniżył poziom detekcji (dobrze oznaczonych) pasów ruchu do 78.51\% (z 98.16\% dla dobrej pogody) oraz wymusił zmniejszenie prędkości samochodu, to trasę udało się ukończyć [31]. Innym pomysłem na usprawnienie działania samochodu autonomicznego podczas złej pogody, jest odpowiednie konstruowanie infrastruktury drogowej. Za przykład mogłyby posłużyć sygnalizatory świetlne wyposażane w moduł wysyłający informacje do pojazdów autonomicznych.

Analiza materiałów przedstawionych w artykule wykazuje, że chociaż podejmuje się wiele prób usprawnienia funkcjonowania samochodu autonomicznego w złych warunkach atmosferycznych to jednak problem ten daleki jest od rozwiązania. Rozwój technologii i ulepszenie sensorów, a także usprawnienie algorytmów dokonujących interpretacji zebranych danych wraz z tworzeniem systemów opartych o kilka czujników, mogą w przyszłości przynieść rozwiązanie tych kwestii.

Przedstawiony materiał pokazuje złożoność problemu a jego rozwiązanie będzie stanowiło znaczny krok w autonomizacji pojazdów. W ramach przyszłych prac, pragnie się stworzyć stanowisko badawcze oraz podjąć dalsze badania i symulacje związane $\mathrm{z}$ analizują i usprawnianiem działania LiDARu w niesprzyjających warunkach atmosferycznych.

\section{LITERATURA}

1. ALDIBAJA M., SUGANUMA N., YONEDA K.: Improving localization accuracy for autonomous driving in snow-rain environments, System Integration (SII), IEEE/SICE International Symposium on, 2016, str. 212-217.

2. ANDERSON J., KALRA N., STANLEY K., SORENSEN P., SAMARAS C., OLUWATOLA O. AUTONOMOUS.: Vehicle Technology A Guide for Policymakers. RAND CORPORATION. (2014) str. 60

3. BIJELIC M., GRUBER T., RITTER W.: Benchmarking Image Sensors Under Adverse Weather Conditions for Autonomous Driving, IEEE Intelligent Vehicles Symposium (IV), 2018.

4. BLIN R., AINOUZ S., CANU S., MERIAUDEAU F.: Road scenes analysis in adverse weather conditions by polarization-encoded images and adapted deep learning, 2019,

https://www.researchgate.net/publication/336510493_Road_scenes_analysis_in _adverse_weather_conditions_by_polarization-

encoded_images_and_adapted_deep_learning. Dostęp 2021-07-08

5. BRUMMELEN J, O’BRIEN M, GRUYER D, NAJJARAN, H.: Autonomous vehicle perception: The technology of today and tomorrow, Transportation Research Part C 89 (2018) str. 384-406

6. CACCIA L., HOOF H.V., COURVIlle A., PINEAU J.: Deep Generative modeling of LiDAR Data, IEEE/RSJ International Conference on Intelligent Robots and Systems (IROS), 2019.

7. CAI B., XU X., JIA K., QING C., TAO D.: DehazeNet: an end-to End system for single image haze removal, IEEE Trans. Image Process. 25(2016)11, 2016, $5187-$ 5198. 
8. CHRONOMAŃSKI W., GRABEK I., KOZŁOWSKI M., CZEREPICKI A., MARCZUK K.: Pojazdy Autonomiczne i Systemy Transportu Autonomicznego, Wydawnictwo Naukowe PWN, Warszawa 2020, str. 123-147.

9. DUTHON P., BERNARDIN F., CHAUSSE F., COLOMB M.: Methodology used to evaluate computer vision algorithms in adverse weather conditions, Transportation Research Procedia 14, 2016, str. 2178 - 2187.

10. ESKANDARIAN A.: Handbook of Intelligent Vehicles, Springer, 2012, Volume 2, str. 38, 171, 767, 1006, 1039.

11. FARAHNAKIAN F, HEIKKONEN J.: Deep learning based multi-modal fusion architectures for maritime vessel detection. Rem Sens, 2020, 12(16):2509.

12. FERREIRA J., MARTINS A., MONTEIRO V.: Intelligent Transport Systems, From Research and Development to the Market Uptake, Challenges in Object Detection Under Rainy Weather Conditions, Springer, 2018 str. 53-66

13. FILGUEIRA A., GONZÁLEZ-JORGE H., LAGÜELA S., DÍAZ-VILARIÑO L., ARIAS P.: Quantifying the influence of rain in LiDAR performance, Measurement 95, 2017, str. 143-148.

14. FU X., HUANG J., ZENG D., HUANG Y., DING X., PAISLEY J.: Removing rain from single images via a deep detail network, Proceedings of the IEEE Conference on Computer Vision and Pattern Recognition, 2017, str. 3855-3863.

15. GARG, K., S. NAYAR.: Photometric Model of a Rain Drop. (2003). https://www.semanticscholar.org/paper/Photometric-Model-of-a-Rain-DropGarg Nayar/80c15084bcfa4635f70cc51e13666eff14a94f45 01.08.2021

16. GEHRIGA S., SCHNEIDERA N., STALDERB R., FRANKE U.: Stereo vision during adverse weather - Using priors to increase robustness in real-time stereo vision, Image and Vision Computing 68, (2017), str. 28-39.

17. GIRSHICK R.: Fast r-cnn, Proceedings of the IEEE international conference on computer vision, 2015, str. 1440-1448.

18. GOODIN C., CARRUTH D., DOUDE M., HUDSON C.: Predicting the Influence of Rain on LIDAR in ADAS, Electronics 8(1), 2019, str. 89.

19. GRUYER D., MAGNIER V., HAMDI K., CLAUSSMANN L., ORFILA O., RAKOTONIRAINY A.: Perception, information processing and modeling: Critical stages for autonomous driving applications, Annual Reviews in Control, Volume 44, 2017, str. 323-341.

20. GUPTA A., ANPALAGAN A., GUAN L., KHWAJA A.: Deep learning for object detection and scene perception in self-driving cars: Survey, challenges, and open issues, Array 10, (2021) str. 100057.

21. HADJ-BACHIR M., PHILIPPE DE SOUZA.: LIDAR Sensor Simulation in Adverse Weather Condition for Driving Assistance Development, hal-01998668, 2019, dostęp: 2021-07-08 https://hal.archives-ouvertes.fr/hal01998668/document.

22. HASIRLIOGLU S., KAMANN A., IGOR DORIC I., BRANDMEIER T.: Test Methodology for Rain Influence on Automotive Surround Sensors, IEEE 19th International Conference on Intelligent Transportation Systems (ITSC), str. 2242 22472016.

23. HESPEL L., RIVIERE N., HUET T., TANGUY B., CEOLATO R.: Performance evaluation of laser scanners through the atmosphere with adverse condition, pp. 818 606-818 606-15, 2011. [Online]. dostęp 2021-07-08: http://dx.doi.org/10.1117/12.898010. 
24. HNEWA M., RADHA H.: Object Detection Under Rainy Conditions for Autonomous Vehicles: A Review of State-of-the-Art and Emerging Techniques, IEEE Signal Processing Magazine, vol. 38, no. 1, 2021, str. 53-67.

25. HOU G., CHEN S., CHEN F.: Framework of simulation-based vehicle safety performance assessment of highway system under hazardous driving conditions, Transportation Research Part C: Emerging Technologies, Volume 105, (2019), str. 23-36.

26. JIANG K., YANG D., LIU C., ZHANG T., XIAO Z.: A Flexible Multi-Layer Map Model Designed for Lane-Level Route Planning in Autonomous Vehicles, Engineering, Volume 5, Issue 2, 2019, str. 305-318.

27. JOKELA M., MATTI KUTILA M. PYYKÖNEN P.: Testing and Validation of Automotive Point-Cloud Sensors in Adverse Weather Conditions, applied sciences 9, 2019, str.2341.

28. KHATAB E., ONSY A., VARLEY M., ABOUELFARAG A.: Vulnerable objects detection for autonomous driving: A review, Integration, Volume 78, 2021, str. 36-48.

29. KRYVINSKA N., PONISZEWSKA-MARANDA A., GREGUS M.: An Approach towards Service System Building for Road Traffic Signs Detection and Recognition, Procedia Computer Science, Volume 141, (2018), str. 64-71.

30. KUTILA M., PYYKÖNEN P., RITTER W., SAWADE O., SCHÄUFELE B.: Automotive LIDAR Sensor Development Scenarios for Harsh Weather Conditions, IEEE 19th International Conference on Intelligent Transportation Systems (ITSC), 2016.

31. LEE U., JUNG J., SEOKWOO JUNG S., SHIM D.H.: Development of a selfdriving car that can handle the adverse weather, International Journal of Automotive Technology, Vol. 19, No. 1, 2018, str. 191-197.

32. LI C-J., QU Z., WANG S-Y., LIU L.: A method of cross-layer fusion multi-object detection and recognition based on improved faster R-CNN model in complex traffic environment, Pattern Recognition Letters, Volume 145, 2021, str. 127-134.

33. LI G., YANG Y., ZHANG T., QU X., CAO D., CHENG B., LI K.: Risk assessment based collision avoidance decision-making for autonomous vehicles in multi-scenarios, Transportation Research Part C: Emerging Technologies, Volume 122, (2021), str. 102820.

34. LIU M.-Y., BREUEL T., KAUTZ J.: Unsupervised image-to-image translation networks, Advances in neural information processing systems, 2017, str. 700 708.

35. M. KUTILA, P. PYYKONEN, H. HOLZHUTER, M. COLOMB, P. DUTHON.: Automotive LiDAR performance verification in fog and rain, Proceedings of 2018 21st International Conference on Intelligent Transportation Systems, 2018.

36. MAURER M., GERDES J., LENZ B., WINNER H.: Autonomous Driving Technical, Legal and Social Aspects, Springer Open, (2016), str. 355, 356

37. ONDRUŠ J., KOLLA E., VERTAL P., ŠARIĆ Ž.: How Do Autonomous Cars Work?, Transportation Research Procedia Volume 44, (2020), str. 226-233

38. PEYNOT T., UNDERWOOD J., SCHEDING S.: Towards reliable perception for unmanned ground vehicles in challenging conditions, IEEE/RSJ Int. Conf. on Intelligent Robots and Systems, 2009, str. 1170- 1176, 
39. QI C.R., LIU W., WU C., SU H., GUIBAS L.J.: Frustum PointNets for 3D Object Detection from RGB-D Data, Proceedings of the IEEE Conference on Computer Vision and Pattern Recognition (CVPR), 2018, str. 918-927

40. QIAN R., TAN R. T., YANG W., SU J., LIU J.: Attentive generative adversarial network for raindrop removal from a single image, Proceedings of the IEEE Conference on Computer Vision and Pattern Recognition, 2018, str. 2482-2491.

41. RASSHOFER, R.H., SPIES, M., SPIES, H.: Influences of weather phenomena on automotive laser radar systems. Adv. Radio Sci. 9, 2011, str. 49-60.

42. REDMON J., DIVVALA S., GIRSHICK R., FARHADI A.: You only look once: Unified, real-time object detection, IEEE Conference on Computer Vision and Pattern Recognition (CVPR), 2016, str. 779- 788.

43. REN D., ZUO W., HU Q., ZHU P., MENG D.: Progressive image deraining networks: a better and simpler baseline, Proceedings of the IEEE Conference on Computer Vision and Pattern Recognition, 2019, str. 3937-3946.

44. SAE International. 2021. Dostęp 2021-07-08. https://www.sae.org/news/pressroom/2018/12/sae-international-releases-updated-visual-chart-for-its$\%$ E2\%80\%9Clevels-of-driving-automation $\%$ E2\%80\%9D-standard-for-selfdriving-vehicles

45. SAKARIDIS C, DAI D, VAN GOOL L.: Semantic foggy scene understanding with synthetic data. International Journal of Computer Vision, 2018, 126(9) str.973-992,

46. SCHECHNER Y., NARASIMHAN S., NAYAR S.: Instant dehazing of images using polarization, Conference on Computer Vision and Pattern Recognition, 2001, vol. 1, pp. 325-332,

47. SHIT R.: Precise localization for achieving next-generation autonomous navigation: State-of-the-art, taxonomy and future prospects, Compter Communications, Volume 160, (2020), str. 351-374.

48. SLUTSKY M., DOBKIN D.: Dual inverse sensor model for radar occupancy grids, Proceedings of 2019 IEEE Intelligent Vehicles Symposium, 2019, str. $1550-1557$.

49. STEINHAUSER D., HELD P., THORESZ B., BRANDMEIER T.: Towards Safe Autonomous Driving: Challenges of Pedestrian Detection in Rain with Automotive Radar, 17th European Radar Conference (EuRAD), 2020.

50. WOJTANOWSKI J., ZYGMUNT M., KASZCZUK M., MIERCZYK Z., MUZAL M.: Comparison of $905 \mathrm{~nm}$ and $1550 \mathrm{~nm}$ semiconductor laser rangefinders' performance deterioration due to adverse environmental conditions. Opto-Electron. Rev. 22(3), 2014, str. 183-190.

51. YADAV G., MAHESHWARI S., AGARWAL A.: Fog removal techniques from images: A comparative review and future directions, Signal Propagation and Computer Technology (ICSPCT), 2014, str. 44-52.

52. YAMADA M., SATOT., CHISHIRO H., KATO S.: Vision-based Localization using a Monocular Camera in the Rain, IEEE Intelligent Transportation Systems Conference (ITSC), 2019, DOI: 10.1109/ITSC.2019.8917241

53. YANG M., WANG X., QUDDUS M.: Examining lane change gap acceptance, duration and impact using naturalistic driving data, Transportation Research Part C: Emerging Technologies, Volume 104, (2019) str. 317-331. 
54. YAZDAN R. VARSHOSAZ M.: Improving traffic sign recognition results in urban areas by overcoming the impact of scale and rotation, ISPRS Journal of Photogrammetry and Remote Sensing Volume 171, (2021), str. 18-35.

55. YONEDA K, SUGANUMA N., YANASE R., ALDIBAJA M.: Automated driving recognition technologies for adverse weather conditions, , IATSS Research 43 (2019) str. 253-262

56. ZANG S., DING M.: The Impact of Adverse Weather Conditions on Autonomous Vehicles: Examining how rain, snow, fog, and hail affect the performance of a self-driving car, March 2019IEEE Vehicular Technology Magazine PP(99):1-1, DOI:10.1109/MVT.2019.2892497

57.ZHANG C., MARCELO H. ANG, RUS D.: Robust LIDAR Localization for Autonomous Driving in Rain, 2018 IEEE/RSJ International Conference on Intelligent Robots and Systems (IROS), 2018.

58. ZIMMERMANN M., WOTAWA.: An adaptive system for autonomous driving, Software Quality Journal, (2020), 28:1189-1212. 